\title{
THE CONSTRUCTION OF A PROFESSIONAL MODEL OF PHYSICAL EDUCATION TEACHERS IN COLLEGES AND UNIVERSITIES FROM THE PERSPECTIVE OF PUBLIC HEALTH SERVICE
}

\author{
CONSTRUÇÃO DE UM MODELO PROFISSIONAL DE PROFESSORES DE EDUCAÇÃO FÍSICA EM FACULDADES \\ EUNIVERSIDADES SOB A PERSPECTIVA DO SERVIÇO DE SAÚDE PÚBLICA
}

\section{CONSTRUCCIÓN DEL MODELO PROFESIONAL DE DOCENTES DE EDUCACIÓN FÍSICA EN COLEGIOSY Y UNIVERSIDADES DESDE LA PERSPECTIVA DEL SERVICIO DE SALUD PÚBLICA}

\section{Dan Shan'1(D) \\ (Sports Engineering) \\ 1. College of Mathematics, Jilin Normal University, Siping, Jilin, China.}

\section{Correspondence:}

Siping 136000, Jilin, China. yoswqd@163.com

\begin{abstract}
With the continuous improvement of people's material living standards, public health and national fitness has become a social topic, and has been widely concerned by the public, in terms of the traditional physical education and impact of the concept of health. This not only needs the school to carry on the multi-directional adjustment to the physical education teaching, but also needs the physical education teacher to respond positively to this in order to adapt to the development needs of the times and society. This study uses the analytic hierarchy process (AHP) to construct the professionalization model of physical education teachers in Colleges and Universities, and makes decision on the index weight of the model through fuzzy comprehensive evaluation. The results show that the weight of the first-class indicators of P.E. Teachers' professionalization model from large to small is ability > quality > knowledge, and the consistency ratio (CR) of the model indicators is less than 0.1 , and the fuzzy score of the model is 85 points. Therefore, the model of P.E. Teachers'professionalization constructed in this study has consistent indicators and shows good applicability. This does not only provide the basis for the professional development evaluation of College PE teachers, but also provides research ideas for the development of the sports industry from the perspective of public health.
\end{abstract}

Keywords: Public health; physical education teachers; professionalization; analytic hierarchy process; fuzzy decision-making.

\section{RESUMO}

Com a melhoria contínua dos padrões de vida materiais das pessoas, a saúde pública e a saúde nacional tornaram-se um tema social, e tem sido amplamente discutido pelo público, em termos de educação física tradicional e impacto do conceito de saúde, que depende não só da escola para continuar o ajuste multidirecional para o ensino de educação física, mas também precisa do professor de educação física para dar uma resposta positiva a isso, a fim de se adaptar às necessidades de desenvolvimento dos tempos e da sociedade. Este estudo utiliza o processo hierárquico analítico (AHP) para construir o modelo de profissionalização dos professores de educação física em faculdades e universidades, e toma uma decisão sobre o peso do índice do modelo através de uma avaliação abrangente. Os resultados mostram que o peso dos indicadores de primeira classe do modelo de profissionalização dos professores de grande para pequeno é a capacidade > qualidade > conhecimento, e a razão de consistência dos indicadores do modelo é menor que 0.1, e a pontuação difusa do modelo é 85 pontos. Assim, o modelo de profissionalização dos professores de educação física, construído neste estudo, tem boa consistência de indicadores e mostra boa aplicabilidade. Isto não só proporciona a base para a avaliação do desenvolvimento profissional dos professores universitários de educação física, mas também fornece ideias de investigação para o desenvolvimento da indústria desportiva sob a perspectiva da saúde pública.

Descritores: Saúde pública; professores de educação física; profissionalização; processo de hierarquia analítica; tomada de decisão difusa.

\section{RESUMEN}

Con la mejora continua del nivel de vida material de las personas, la salud pública y la buena condición física nacional se han convertido en un tema social, y han sido motivo de una amplia preocupación en la población, con respecto a la educación física tradicional y su impacto en el concepto de salud. Esto no solo necesita que la escuela lleve a cabo el ajuste multidireccional de la enseñanza de educación física, sino también que el docente de educación física responda positivamente para adaptarse a las necesidades de desarrollo de los tiempos y la sociedad. Este estudio utiliza el proceso de jerarquía analítica (PJA) para construir el modelo de profesionalización de los docentes de educación física en los colegios y universidades, y analiza el peso del índice del modelo 
a través de una evaluación integral difusa. Los resultados muestran el peso de los indicadores de primera clase del modelo de profesionalización de los docentes, de mayor a menor, es capacidad > calidad > conocimiento, y el índice de consistencia (IC) de los indicadores del modelo es menor a 0.1, y la puntuación difusa del modelo es de 85 puntos. Por tanto, el modelo de profesionalización docente construido en este estudio tiene indicadores consistentes y muestra buena aplicabilidad. Esto no solo proporciona la base para la evaluación del desarrollo profesional de los profesores de educación física universitaria, sino que también ofrece ideas de investigación para el desarrollo de la industria del deporte desde la perspectiva de la salud pública.

Descriptores: Salud pública; profesores de educación física; especialización; análisis de niveles; ambigüedad en la adopción de decisiones.

\section{INTRODUCTION}

In the current construction of China's modernization, sports construction is not only a strong state of the country, but also an important guarantee for people's healthy life. For school education, improving the quality and level of physical education and promoting the reform and innovation of physical education are of great significance to improve students' physical quality and mental health. Iserbyt et al. discussed the differences of teaching content knowledge in content knowledge and physical education, and found through experiments that content knowledge can effectively improve the knowledge understanding degree in the process of physical education teaching, and then improve students' sports technical efficiency and sports performance. ${ }^{1}$ Physical education teachers are the key to physical education. Their professional ability determines the quality of physical education. In the new era of national fitness, physical education teachers need to combine with the requirements of the development of the times, based on the essence of physical education, improve their professional ability, and form the core competitiveness of occupation, so as to adapt to the professional requirements of the new era for physical education teachers. From the perspective of public health, this study will analyze the professional ability needs of College Physical Education Teachers in the new era, in order to provide some suggestions for improving the professional ability of physical education teachers.

On the basis of self-determination theory, through comparative experiments and intervention measures, Cuevas R et al. Found that sports education model can significantly improve sports self-determination behavior. ${ }^{2}$ Jeffery et al. have studied the efficiency of physical education in fitness units. Through health knowledge verification and hierarchical test evaluation, it is found that fitness test and knowledge test have significant time effect, and the combination of effective sports fitness mode is an important way to improve students'fitness skills and health knowledge. ${ }^{3}$ Madbouly, the first mock exam model of classroom acoustics was built by AHP. The priority and corresponding weight of evaluation index were determined through questionnaires and AHP. This model significantly improved the quality of education environment and teaching efficiency of universities. ${ }^{4}$ Daniawan B used the method of questionnaire survey and ahp-saw weighted analysis to study the teaching performance evaluation of lecturers. The results showed that the standard weighted accuracy rate of 28 lecturers reached $90.39 \%$, which greatly improved the efficiency of evaluation analysis while ensuring the accuracy rate. ${ }^{5}$ Goyal et al. proposed an optimization model based on Fuzzy Analytic Hierarchy Process (FAHP) for nonlinear problems, and solved the problem of inconsistent weights with a new constraint condition. Finally, it was compared with other optimization models, and it was found that this model has better consistency weight for multi criteria decision-making system. ${ }^{6}$ In order to improve the language intelligibility in the teaching process, Nowowiat et al. Proposed a classroom sound adaptation scheme based on analytic hierarchy process (AHP), determined the priority and importance of the main standards through measurable calculation, and demonstrated the feasibility of this scheme from two aspects of acoustic parameters and implementation cost. ${ }^{7}$

To sum up, public health and physical fitness are world-wide issues, they not only have social attributes, but also related to everyone's health. In the current physical education research, model education has great research and application potential. Education evaluation is the key point of education quality control. It is an important means to improve the level of teaching quality to construct teaching evaluation model through different research methods and allocate index weight. This study will build a professional model of physical education teachers from the perspective of public health services, so as to improve the quality of physical education.

\section{PE Teachers' professionalization model from the perspective of public health service}

Since this research is from the perspective of public health, the professional model of physical education teachers should be aimed at improving students' physical fitness initiative, so as to ensure that the professional development of physical education teachers is consistent with the needs of students. In order to verify the hierarchical structure model of P.E. Teachers' professionalization constructed by this research, a questionnaire survey will be conducted among the P.E. Majors in M University. Figure 1 shows the data structure of M University's questionnaire survey. A total of 500 questionnaires were distributed, 455 were recovered and 425 were valid. The recovery rate of the questionnaire was $91 \%$, and the effective rate of the questionnaire was $85 \%$. Therefore, the proportion of the valid questionnaire to the returned questionnaire was $93.41 \%$.

Due to the space limitation, English codes are used to indicate all levels of indicators in the results. In the first level index, a is knowledge, B is quality, and C is ability. In the secondary indicators, A1 represents subject knowledge, A2 represents other knowledge, A3 represents basic knowledge; $B 1$ represents psychological quality, B2 represents social quality, B3 represents cultural quality, B4 represents physical quality; $\mathrm{C} 1$ represents teaching ability, C2 represents innovative thinking ability, C3 represents scientific research ability, and C 4 represents cooperative organization ability.

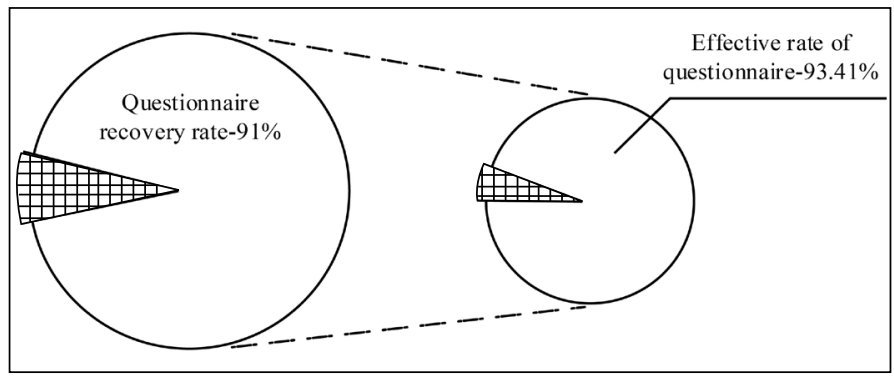

Figure 1. Data structure of M University questionnaire survey. 
Table 1 shows the results of index weight distribution of PE Teachers' professionalization model. According to the weight distribution results of the professionalization model, it can be seen that in the first level indicators, the physical education teachers from the perspective of public health have relatively higher ability requirements, followed by quality requirements, and relatively low requirements for knowledge level. From the perspective of public fitness program, it is mainly reflected in the lack of public fitness programs among young students. Therefore, in the current social environment, the professionalization model of college physical education teachers is guided by professional ability requirements, supplemented by knowledge requirements and quality requirements. In the same way, this paper analyzes the secondary indicators of PE Teachers' professionalization model. For the knowledge requirements of P.E. teachers, it is the most important to master the subject knowledge of P.E. major, followed by the mastery of basic knowledge. From the perspective of the quality requirements of physical education teachers, the professional model has the highest requirements for physical quality, psychological quality and social quality, and relatively low requirements for cultural quality. In the model of P.E. Teachers' professionalization, the most important is the ability requirement, and the teaching ability of $\mathrm{PE}$ teachers is the key to determine their ability value, followed by the ability of cooperative organization. The public health service requires less innovative thinking ability and scientific research ability of physical education teachers. In addition, according to the consistency test results of professional model indicators, it can be seen that the consistency ratio CR of model indicators is less than 0.1 , so the weight distribution of model indicators has high rationality.

After the index weight distribution and consistency test of the professionalization model, it is necessary to conduct fuzzy comprehensive evaluation on the professionalization model. Table 2 shows the calculation results of the fuzzy judgment matrix of the professionalization model index of college physical education teachers. According to formula (4), the fuzzy comprehensive evaluation matrix of the professionalization model can be calculated. According to the calculated fuzzy comprehensive evaluation matrix and fuzzy comprehensive evaluation table, the score of the model constructed in this study is 85 points, which shows that the professional model of physical education teachers based on public health service has good applicability. With the improvement of public health service demand, physical education teachers should keep pace with the times in their own career planning, and have high standards and strict requirements for their own physical education ability. Only by integrating their professional abilities can they be used flexibly in the teaching process.

\section{CONCLUSIONS}

With the implementation and development of the national fitness program, sports and health has become a public topic. In the social grass-roots construction, sports construction has become an urgent
Table 1. Results of index weight distribution of PETeachers' professionalization model.

\begin{tabular}{|c|c|c|c|}
\hline Primary indicators & \multicolumn{2}{|c|}{ Secondary indicators } & $C R$ \\
\hline \multirow{3}{*}{$\begin{array}{c}\text { A } \\
(0.244)\end{array}$} & $\mathrm{A} 1$ & 0.530 & \multirow{3}{*}{$0.0357<0.1$} \\
\hline & $\mathrm{A} 2$ & 0.110 & \\
\hline & A3 & 0.360 & \\
\hline \multirow{4}{*}{$\begin{array}{c}\text { B } \\
(0.326)\end{array}$} & B1 & 0.245 & \multirow{4}{*}{$0.0691<0.1$} \\
\hline & B2 & 0.230 & \\
\hline & B3 & 0.170 & \\
\hline & B4 & 0.355 & \\
\hline \multirow{4}{*}{$\underset{(0.430)}{C}$} & $\mathrm{C} 1$ & 0.442 & \multirow{4}{*}{$0.0532<0.1$} \\
\hline & $\mathrm{C} 2$ & 0.164 & \\
\hline & $\mathrm{C} 3$ & 0.158 & \\
\hline & $\mathrm{C} 4$ & 0.236 & \\
\hline
\end{tabular}

Table 2. Calculation results of fuzzy judgment matrix of professionalization model indicators.

\begin{tabular}{c|cccc}
\hline Index & Results of fuzzy comprehensive evaluation \\
\hline$A$ & {$\left[\begin{array}{lllll}0.014 & 0.121 & 0.272 & 0.392 & 0.199\end{array}\right]$} \\
\hline$B$ & {$\left[\begin{array}{lllll}0.011 & 0.079 & 0.292 & 0.343 & 0.284\end{array}\right]$} \\
\hline C & {$\left[\begin{array}{lllll}0.009 & 0.108 & 0.246 & 0.395 & 0.240\end{array}\right]$} \\
\hline
\end{tabular}

task. Facing the current social environment and industry development, physical education teachers also need to keep up with the trend of the times, from the perspective of public health to think about new breakthroughs in physical education. This study uses the analytic hierarchy process to build the professional model of physical education teachers, and uses the fuzzy decision theory to make the index weight decision of the model. In order to verify the validity of the model, this paper selects the sports major students of M University to conduct a questionnaire survey and score the professionalization model. The results show that, in the professionalization model of physical education teachers, ability accounts for the highest weight of 0.430 , followed by the quality of 0.326 , the proportion of knowledge is the smallest, 0.244 ; the consistency test results of model indicators are less than 0.1; in the fuzzy comprehensive score, the professional model score is 85 points, the evaluation result is good. The research results show good applicability and high consistency, which has certain reference significance for the education development of College Physical Education and the professional development of physical education teachers. In addition, there are still some deficiencies in this study. For example, only one university was selected for the questionnaire survey in the model validation experiment, which is not comparable. This will be improved in the future research.

The author declare no potential conflict of interest related to this article

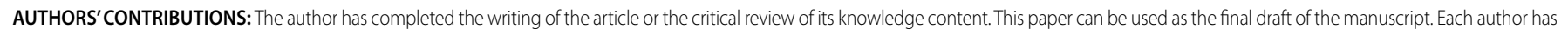
made an important personal contribution to this manuscript. Dan Shan: writing and executing manuscripts.

\section{REFERENCES}

1. Iserbyt $P$, Ward $P$, Martens J. The influence of content knowledge on teaching and learning in Traditional and Sport Education contexts: an exploratory study. Physical Education \& Sport Pedagogy. 2016; 5(21):539-56.

2. Cuevas R, García-López LM, Luis Miguel, Serra-Olivares J. Sport education model and self-determination theory. Kinesiology. 2016; 48(1):30-38.

3. Ward J, Hastie P, Wadsworth DD, Shelby F. A Sport Education Fitness Season's Impact on Students' Fitness Levels, Knowledge, and In-Class Physical Activity. Research Quarterly for Exercise \& Sport. 2017; 3(88):346-351.

4. Madbouly Al, Noaman AY, Hamid MA. Ragab, Khedra, AM, Fayoumi AG. Assessment model of classroom acoustics criteria for enhancing speech intelligibility and learning quality. Applied Acoustics. 2016; 114(12):147-58.

5. Daniawan B. Evaluation of Lecturer Teaching Performance Using AHP and SAW Methods. Bit-Tech. 2018; 1(2):30-39.

6. Goyal RK, Kaushal S. A constrained non-linear optimization model for fuzzy pairwise comparison matrices using teaching learning based optimization. Applied Intelligence. 2016; 45(3):652-661.

7. Nowowiat A, Szurman F. Application of the analytic hierarchy process (AHP) for acoustic adaptation of classrooms. Architecture, Civil Engineering. Environment. 2017; 21(4):45-52. 